\title{
Distribution of Sceliphron destillatorium Illiger, 1807 (Hymenoptera, Sphecidae) in Poland
}

\author{
Piotr BILAŃSKI*, Zbigniew KolODZIE J** and Marek PAJĄK*** \\ * Department of Forest Protection, Forest Entomology and Climatology, Faculty of Forestry, University of \\ Agriculture in Krakow, al. 29. Listopada 46,31-425 Kraków, Poland; e-mail rlbilans@cyf-kr.edu.pl \\ ** Depariment of Silviculture, Faculty of Forestry, University of Agriculture in Krakow, al. 29. Listopada 46, $31-425$ \\ Kraków, Poland; e-mail: rkolodz@ cyf-kr.edu.pl \\ ***Department of Forest Ecology, Faculty of Forestry, University of Agriculture in Krakow, al. 29. Listopada 46, 31 - \\ 425 Kraków, Poland; e-mail rlpajak@cyf-kr.edu.pl
}

\begin{abstract}
There have been 49 confirmed localities of Sceliphron destillatorium Illiger, 1807 in Poland, including 39 documented localities and 10 undocumented localities requiring confirmation. Based on the locations of new localities of $S$. destillatorium as well as those already known from the literature, it has been possible to map where in Poland this species appears as well as the northern limits of its range.
\end{abstract}

Key words: expansion, digger wasp, new records

\section{INTRODUCTION}

European fauna of mud-daubing wasps (genus Sceliphron Latreille) including introduced species comprises 7 representatives: Sceliphron caementarium (Drury, 1770), Sceliphron curvatum (Smith, 1870), Sceliphron destillatorium (Illiger, 1807), Sceliphron funestum (Koh1, 1918), Sceliphron madraspatanum ssp. tubifex (Latreille, 1809), Sceliphron spirifex (Linnaeus, 1758) (Vecht \& Breugel 1968, Hensen 1987) and recently found Sceliphron deforme (Smith, 1856) (ĆETKOvić et al. 2004). Two of them $S$. destillatorium and $S$. curvatum are present in Poland. Information about distribution of $S$. curvatum in Poland will be presented in next article.

S. destillatorium is a large, contrastingly coloured species of the order Hymenoptera, the recognition and observation of which is relatively simple. For this reason, and because of traces of its existence in the form of clay nests located inside and outside various types of buildings, much information can be obtained even from a novice amateur naturalist. Unfortunately, the bright coloration of this species is just as often the cause of its demise, as it is frequently mistaken for an aggressive wasp and killed as a result. It is also often the case that $S$. destillatorium nests found on buildings are destroyed. Only nests built in hard-to-reach places such as on chimneys or in the corners of attics have a chance to survive. The problem of observing new localities is tied to the locations of nests, because oftentimes the observation of nests requires attaining permission from building owners.

In Poland, the occurrence of $S$. destillatorium is tied with human habitations. In areas lacking natural sites suited for nest-building, $S$. destillatorium makes use of buildings. One factor lending itself to this species' settlement in a given area is an abundance of muddy places nearby. In Poland, such places include the edges of rivers and ponds as well as muddy roads and fields in rural areas. Kazenas $(1998,2001,2002)$ also noted this factor beyond Poland. In recent years, the number of rural ponds and residential ponds has been increasing which may influence this species' success in colonizing new areas. 
Sceliphron destillatorium inhabits the southern Palaearctic. In Poland, the first localities were noted in the eastern and southeastern parts of the country in the 1960s (Vecht \& Breugel 1968 ) and 1970s (Soszyński \& Soszyński 1985). For some time, the territory inhabited by this species has undergone expansion. Evidence of this is the rise in the number of known localities of $S$. destillatorium in Poland as well as in neighbouring countries like Germany (Gauss 1997, Stalling 2002), the Czech Republic (Lukáš et al. 2006, Bogusch et al. 2007), or Slovakia (Lukáš 2003, Panigaj 2003, Lukáš et al. 2006, Bogusch et al. 2007).

The goal of this work is to present the current state of knowledge concerning the distribution of localities of $S$. destillatorium in Poland. Localities already known from the literature are placed side-by-side with those discovered during the investigations.

\section{Legend}

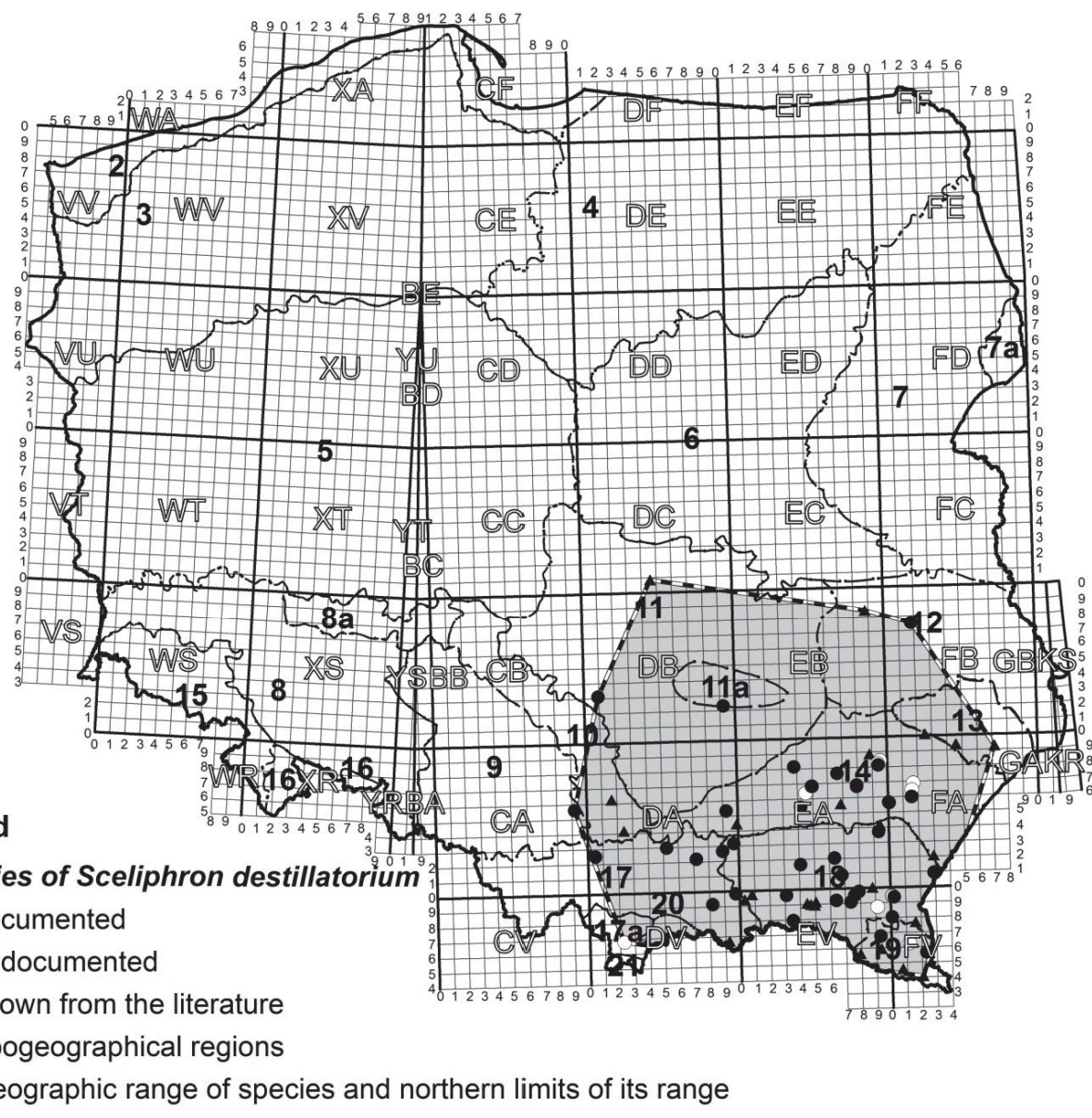

Fig. 1. Distribution map of Sceliphron destillatorium Illiger, 1807 in Poland and northern limits of its range (UTM grid map). Zoogeographical regions according to the Catalogue of Fauna of Poland (Burakowski et al. 2000): 1 - the Baltic Sea (it is not marked in the map), 2 - the Baltic Coast, 3 - the Pomeranian Lake District, 4 - the Masurian Lake District, 5 - the Wielkopolska-Kujawy Lowland, 6 - the Mazowian Lowland, 7 - the Podlasie Lowland, 7a - the Białowieża Primeval Forest, 8 - Lower Silesia, 8a - the Trzebnickie Hills, 9 - Upper Silesia, 10 - the Kraków-Wieluń Upland, 11 - the Małopolska Upland, 11a - the Świętokrzyskie Mountains, 12 - the Lubelska Upland, 13 - Roztocze, 14 - the Sandomierska Lowland, 15 - the Western Sudetes Mountains, 16 - the Eastern Sudetes Mountains, 17 - the Western Beskidy Mountains, 17a - the Nowotarska Basin, 18 - the Eastern Beskidy Mountains, 19 - the Bieszczady Mountains, 20 - the Pieniny Mountains, 21 - the Tatra Mountains. 


\section{MATERIALS AND METHODS}

From 2003 to 2011, faunal information regarding the occurrence of S. destillatorium was gathered as well as other forms of evidence. During this time, nests were collected, imago breeding was conducted, imagines were gathered outdoors, and discovered localities were photographically documented. The gathered insects and their nests as well as photographic documentation can all be found in the Department of Forest Protection, Forest Entomology and Climatology. Determination and nomenclature were done according to Schmid-Egger (2005). The locations of new as well as already known localities were marked on a map of Poland with a UTM grid. The new localities have been grouped in the text according to zoogeographical areas following the Catalogue of Fauna of Poland (Burakowski et al. 2000). Undocumented localities were also taken into account if their presence in a given area was highly probable based on documented localities. Information concerning localities needing confirmation came mostly from hobbyist naturalists.

The likely extent of occurrence of $S$. destillatorium in Poland was plotted based on the distribution of extreme localities.

The localities of $S$. destillatorium were confirmed in various zoogeographical regions according to the Catalogue of Fauna of Poland (Burakowski et al. 2000) (Fig. 1).

The following abbreviations have been used: collectors' names, PB - Piotr Bilański; f female, $\mathrm{m}$ - male.

\section{RESULTS}

On Polish territory, there has been a total of 49 newly confirmed localities of $S$. destillatorium, including 39 documented cases and 10 undocumented cases requiring confirmation.

\section{The Eastern Beskidy Mountains}

Rozpucie (FV09), 30 X 2003, 2 nests in the attic of a house, leg. et coll. PB; 25 VIII 2009, 11 VII 2010, 2 nests, 2 exx. f, leg. et coll. PB. Observation 12 VII 2010, 1 ex. imago f builds a nest on the eastern facade of a house, Piotr Bilański. July 2010, 1 ex. imago f builds nests on house facade, Kazimierz Nitka oral information. 10 III 2011, 2 nests on the rafters of a woodshed, photographic documentation Piotr Bilański. 3 VII 2011, 2 nests -1 inside of a building in the attic between the rafter and the roof and 1 inside under the roof of a shed; 21 VIII 2011, 4 nests -1 ex. imago f edifying 1 nest, 2 nests on the outside facade in the corners of windows from the east and south, and an unfinished nest in a kitchen behind the curtain, photographic documentation Piotr Bilański. Pakoszówka (EV79) 12 VII 2008, 1 ex. imago m feeding on honeydew from Abies alba Mill. in a garden, photographic documentation Tomasz Maslowski. Żyznów (EA62), 20 XI 2009, a nest in a backpack in an attic, leg. Jaroslaw Szurlej, coll. PB. Bażanówka (EV79), 22 II 2010, a nest, leg. Marcin Plaza, coll. PB; e. 1. 1 V, 2010, 1 ex. imago m coll. PB; e. 1. 21 VI 2010, 1 ex. imago m coll. PB. Biala Niżna (DV99), 19 X 2010, a nest under the roof on polystyrene leg. Marcin Widlak coll. PB; e. 1.25 III 2011, 1 ex. imago m, leg. et coll. PB; e. 1. 2 IV 2011, 1 ex. imago f, leg. et coll. PB. Hermanowice (FA20), $31 \mathrm{X} 2010,2$ nests in the attic of a cottage, leg. Łukasz Plocica, coll. PB. Husów (EA93), 16 IX 2010, 1 nest, leg. Janusz Wrona; e. 1.25 III 2011, 1 ex. imago m, leg. et coll. PB; e. 1.28 III 2011, 1 ex. imago m, leg. et coll. PB. Lubla (EA41), 21 X 2010, 6 nests on the facade of a building, leg. Waldemar Zieliński, coll. PB. Orzechówka (EA60), 17 V 2010, 4 nests, leg. Marek Morajko, coll. PB. Pielgrzymka ad Osiek Jasielski (EV39), 23 X 2010, 5 nests on the facade at the top of a house, photographic documentation Jan Felenczak. Posada Zarszyńska (EV79), June-July 2010, nest in the wall of a building behind timplate, 1 ex. dead $\mathrm{f}$ imago 
inside a building, leg. Pawel Leśniak, imago photographic documentation Piotr Bilański. Woźniczna (DA93), 3 VII 2010, 1 ex. imago f killed in a house, photographic documentation Michal Kocik. Zagórz (EV98), July 2010, observations 4 exx. imagines $f$ at a construction site next to flooded pits under the foundations of the house, Adam Szmilyk oral communication. Żydowskie in Magura National Park (EV37), 1 VIII 2010, a nest on the soffit of a roof from the SW and 1 ex. imago, photographic documentation Milosz Serafin. Janowice (DA82), 16 VI 2011, seven nests under the eaves on the facade of a building from the $E$ and $S$, near two ponds, photographic documentation Piotr Bilański. Rymanów (EV69), 24 IX 2011, 2 nests in the attic of a house, leg. Łukasz Mateusiak, coll. PB; 1 X 2011, 2 exx. dead imagines $\mathrm{f}$ in the attic of a house near the nests, leg. Łukasz Mateusiak, coll. PB; 1 X 2011, 3 nests inside a wooden shed, leg. Łukasz Mateusiak, coll. PB. Uherce Mineralne ad Olszanica (FV08), 1 X 2011, 1 nest inside a tin garage, photographic documentation Mariusz Labaj.

The Western Beskidy Mountains

Kamionka Mala (DV89), 2007, 1 ex. imago; 2008, 1 ex. imago, leg. et coll. Marcin Widlak. Tymowa (DA72), July 2010, 1. ex. imago $\mathrm{m}$, photographic documentation of imago and observation of two nests in the attic of a house Malgorzata Fidzinska. Buczyna ad Bochnia (DA53), 18 VII 2010, 2 exx. imagines observed on Apiaceae Lindl.; 1 ex. imago f, leg. et coll. Marcin Józefczyk. Kalwaria Zebrzydowska (DA02) 3 IX 2011, 1 nest on the facade of two storey block under the roof eaves from the E, photographic documentation Piotr Bilański.

\section{The Bieszczady Mountains}

Chrewt (FV16), July 2003, a nest in a cottage destroyed by the owners by being thrown into Solina Lake, Anonymous oral information. Lutowiska (FV25), 17 XII 2010, 10 nests, leg. Krzysztof Hebda coll. PB, on the chimney in an attic. Since 2005, there is a pond next to the house. E. 1. 25 III 2011, 2 exx. imago m, 1 ex. f, leg. et coll. PB; e. 1.12 IV 2011, 1 ex. imago f, leg. et coll. PB; e. 1. 26 IV 2011, 1 ex. imago f, leg. et coll. PB; e. 1.29 IV 2011, 1 ex. imago m, leg. et coll. PB; e. 1.6 V 2011, 1 ex. imago f, leg. et coll. PB; e. 1.9 V 2011, 1 ex. imago f, leg. et coll. PB; e. 1.14 V 2011, 1 ex. imago m, leg. et coll. PB; e. 1.19 V 2011, 1 ex. imago f, leg. et coll. PB; e. 1.01 VI 2011, 1 ex. imago f, leg. et coll. PB. Mchawa ad Baligród (EV96), 25 IX 2011, 2 nests inside a tin garage, photographic documentation Mariusz Labaj.

\section{The Nowotarska Basin}

Czerwienne, (DV26), 2003, 1 ex. imago, dead imago on a window in a barn, observation Jan Lach. The mountain stream near the farm.

\section{The Sandomierska Lowland}

Krzeszów ad Rudnik nad Sanem, (EA98), 2003-2007, nest and 1. ex. imago, observation Milosz Serafin. Nest was located on the eastern wall inside of an outbuilding (shed). Nests were established periodically since 2003 , the last nest was in 2007 , since its removal, no new nests have been established. Dybków ad Sienawa, (FA15), 21 I 2006, 2 nests inside an attic near a window; 11 VII 2010, 1 ex. imago f feeding on honeydew on Persica vulgaris Mill.; 25 VII 2011, 7 nests inside the attic of a house and outbuilding -6 of which are from previous years and have been partially abandoned, 1 newly completed; 25 VII 2011, two nests under construction in the attic of a building, photographic documentation of imago and nests Tomasz Mikulski. Cieplice ad Sienawa, (FA16), 2009-2010, 1 nest in the corner of a window in a house, near a pond, observation of nest Janusz Starzak. Turza (EA76), 8 VIII 2009, 16 nests leg. Zbigniew Kolodziej coll. PB; 24 VII 2010, two nests in the corners of the facade of a house, Piotr Bilanski photographic documentation. Next to the house is a pond. Over a dozen nests from the attic were destroyed and thrown into the pond. 24 VII 2010, 2 nests in the attic 
of a house and the observation of an ex. imago flying into the attic of a farm building. Observation of imago and photographic documentation of nests Piotr Bilański. Czajkowa (EA38), 3 VIII 2010, a nest on the facade of a residential building, leg. Janusz Wrona coll. PB. Koziarnia ad Rudnik nad Sanem (EA98), 10 VII 2010, 1 ex. imago leg. et coll. Pawel Sowa, a nest in the attic of a house, nearby $(87 \mathrm{~m})$ lies a pond. Observation of the nest in the attic Pawel Sowa. Niwiska (EA46), 22 VII 2010, 1 ex. imago, observed on the flying next to a building, Hubert Jemiolo, oral information. Ocieka (EA45), 29 VI 2010, imago 2 exx. killed on the steps to the porch of a residential building, photographic documentation Hubert Jemiolo. Pocyrchle ad Rudnik nad Sanem (EA98), July 2010, 2 nests, oral information, Pawel Sowa. Rudka ad Sieniawa (FA16), August 2010, 2 exx. imago, observed in a home, nests not found, Bartlomiej Szkamruk oral information. Siedlanka ad Kolbuszowa (EA46), 22 VII 2010, 1 ex. imago f, 1 ex. imago $\mathrm{m}$, leg. et coll. PB. Specimen caught on a meadow near a forest, a few dozen yards away lies a pond. Wilcza Wola (EA67), 13 VII 2010, 1 ex. imago, leg. Zbigniew Kolodziej coll. PB, dead imago on nature path on the shores of the lagoon in Wilcza Wola. Żabno ad Dąbrowa Tarnowska (DA95), July 2010, 1 ex. f, leg. et coll. Mateusz Dydyński, also an ex. imago seen in the summer in a house on the window from the south. At a distance of $750 \mathrm{~m}$ to the east flows a river. Photographic documentation of the imago Piotr Bilański. Zmystówka ad Leżajsk (FA05), 16 VIII 2011, two nests on a garage near a pond, photo documentation and leg. Jerzy Kasprzak; 3 IX 2011, 2 nests inside the attic of a house near a pond, photo documentation Jerzy Kasprzak.

The Lubelska Upland

Świdnik ad Lublin (FB17), 30 VI 2011, 1 ex. imago f, photographic documentation Michal Kocik.

\section{The Malopolska Upland}

Okolowice ad Koniecpol (DB03), 18 VII 2010, 1 ex. imago m., leg. Łukasz Mielczarek, coll. PB.

The Świętokrzyskie Mountains

Cisów ad Daleszyce (DB92), 7 VIII 2011, 6 exx. imagines; 3 exx. imagines leg. et coll. Łukasz Mielczarek; 3 exx. imagines leg. et coll. Cezary Nowak, caught on Heracleum sphondylium L.

Upper Silesia

Mloszowa ad Trzebinia (CA95), 11 VII 2011, 1 f., leg. et coll. Rafal Celadyn, caught on Apiaceae Lind1.

\section{DISCUSSION}

Up to this point, there were 30 known localities of $S$. destillatorium in Poland (Soszyński \& Soszyński 1985, Celary 1996, Celary 1998, Wiśniowski 2000, Zator 2004, Wiśniowski 2007; Kowalczyk et al. 2009; Kosibowicz 2009; Bury et al. 2009). The discovery of 39 new documented localities in southeastern Poland indicates that this species has acclimated itself to the environmental conditions here. The density of localities known from the literature as well as those found during the surveys tends to decrease going from east to west and from south to north, which indicates the directions of expansion of this species in Poland. The first discoveries of this species in Poland in the 1960s and 70s were the result of an increase in the area of occurrence in the surrounding geographical regions, including the European part of Russia (Soszyński \& Soszyński 1985 after Fomichev \& Minoranskij 1971). It is difficult to 
determine whether the then discovered localities of $S$. destillatorium were part of a continuous distribution, or a dotted distribution instead. In the case of localities near Lublin, the latter conjecture is more likely. On the other hand, in the Eastern Beskidy Mountains region, a continuous population distribution seems to be the very likely, based on the more frequent observations of imagines and nests in this part of Poland. Regarding the continuity of the population of $S$. destillatorium in Poland, it is necessary to use the same caution when interpreting currently confirmed localities on the northern and western reaches of this species in Poland.

The expansion of $S$. destillatorium and many other species of similar environmental requirements can be tied to the warming of the climate. However, such conjectures require confirmation, because many factors come into play with regards to the expansion of a species' territorial extent, including intrapopulational factors (i.e. the number of migrating specimens). In new areas, a population is able to free itself, for a time, from some parasites. Stilbum cyanurum cyanurum Först. (Hymenoptera, Chrysididae), a parasite of $S$. destillatorium (Móczár 1961) has not yet to be found in Poland (Bogdanowicz et al. 2004).

A likely critical factor in the density of the $S$. destillatorium population is the distance a female has to fly between her nest and the source of building materials for the nest as well as source of food for her and her larvae. $S$. destillatorium imagines are nectarivores and palynivores, while larvae feed off of spiders gathered in the nest by the female.

Taking into account the observed speed at which $S$. destillatorium has been colonizing Poland in the last few years, new localities claimed by this work to be beyond the territorial extent of this species in Poland, may in reality already be part of the continuous extent of this species in Poland. Localities from around Koniecpol and Łódź were noted a few years ago, while the locality in Kalwaria Zebrzydowska is represented by a nest, which was probably built in 2010. The determination of the exact and realistic extent of $S$. destillatorium in Poland requires continuous commitment to research and many people.

\section{REFERENCES}

Bogdanowicz W., CHUdzicka E., PILIPIUK I. \& SkiBniska E. (eds). 2004. Fauna Polski - Charakterystyka i wykaz gatunków. Tom I, Muzeum i Instytut Zoologii PAN, pp. 509.

BOGUSCH P., STRAKA J. \& KMENT P. 2007 (eds). Annotated checklist of the Aculeata (Hymenoptera) of the Czech Republic and Slovakia. Acta Entomologica Musei Nationalis Pragae, Supplementum 11: 1-300.

Burakowski B., Mroczkowski M. \& Stefańska J. 2000. Chrzązzze Coleoptera, Uzupełnienia tomów $2-21$. Katalog Fauny Polski, Warszawa, XXIII, 22: 1-252.

BURY J., SUdOE D., ZIĘBA P. \& ŻYŁA W. 2009. Nowe dane o występowaniu przedstawicieli rodzaju Sceliphron Klug, 1801 (Hymenoptera, Sphecidae) na terenie Polski. Acta Entomologia Silesiana 17: 11-18.

CELARY W. 1996. Remarks on the biology and distribution of Sceliphron destillatorium (Illiger) (Hymenoptera: Sphecidae) in Poland, Polskie Pismo Entomologiczne 65: 253-256.

CELARY W. 1998. Nowe i rzadkie gatunki żądłówek (Hymenoptera, Aculeata) stwierdzone w południowej Polsce. Chrońmy Przyrodę Ojczystą 54(6): 105-110.

ĆETKOVIĆ A., RADOVIĆ I. \& DOROVIĆ L. 2004. Further evidence of the Asian mud-daubing wasps in Europe (Hymenoptera: Sphecidae). Entomological Science 7: 225-229.

GAUSS R. 1997. Sceliphron - Gast oder Migrant? Bembix 9: 17.

HENSEN R. V. 1987. Revision of the subgenus Prosceliphron van der Vecht (Hymenoptera, Sphecidae). Tijdschrift Voor Entomologie 129: 217-261.

ILLIGER K. 1807. Vergleichung der Gattungen der Hautflügler. Piezata Fabr. Hymenoptera Linn. Jur. Magazin für Insektenkunde 6: 189-199.

KAZENAS V. 1998. Rojushhie osy (Hymenoptera, Sphecidae) Kazahstana. (Podsem. Ampulicinae, Sphecinae). Vypusk 1. Almaty, $377 \mathrm{pp}$.

KAZENAS V. 2001. Fauna i biologiya royushchikh os (Hymenoptera, Sphecidae) Kazakhstana i Sredney Azii. Kazgos INTI, Almaty, 333 pp.

KAZENAS V. 2002. Royushchiye osy (Hymenoptera, Sphecidae) Kazakhstana. Tethys Entomological Research 4: 1173.

KosiBowicz M. 2009. Egzotyczna osa w Krakowie. Wszechświat 4-6: 78-79. 
KOWALCZYK J. K, KURZAC T. \& SOSZYISSKI B. 2009. Nowe stanowiska interesujących gatunków żądlówek (Hymenoptera, Aculeata) w regionie tódzkim. Parki Narodowe i Rezerwaty Przyrody 28 (2): 127-134.

LUKÁŠ J. 2003. Fauna blanokrídlovcov (Hymenoptera) starého ovocného sadu intravilánu Bratislavy. Folia faunistica Slovaca 8: 71-74.

LUKÁŠ J., BOGUSCH P. \& LIŠKA P. 2006. Distribution of Sceliphron destillatorium (Illiger, 1807) (Hymenoptera: Sphecidae) in Moravia and Slovakia with notes on the invasion to the antropogenous localities. Linzer Biologische Beitraege 38: 521-528.

MóczÁR L. 1961. On the habits of Stilbum cyanurum cyanurum Forst. (Hymenoptera, Chrysididae). Annales Historico-Naturales Musei Nationalis Hungarici 53: 463-466.

PANIGAJ L. 2003. K výskytu niektorých zaujímavých druhov bezstavovcov (Evertebrata) zistených počas XXVII. VSL TOP-u vo Vyšnej Pisanej [in] Zborník výsledkov prác odborných sekcií XXVII. Východoslovenského tábora ochrancov prírody $84-87$.

SCHMID-EGGER C. 2005. Sceliphron curvatum (F. Smith 1870) in Europa mit einem Bestimmungsschlüssel für die europäischen und mediterranen Sceliphron-Arten (Hymenoptera, Sphecidae). Bembix 19: 7-28.

SOSZYŃSKI B. \& SOSZYNiski M. 1985. Sceliphron destillatorium (ILL.) (Hymenoptera, Sphecidae) w Polsce. Polskie Pismo Entomologiczne 55: 213-215.

STALLING T. 2002. Erster Fortpflanzungsnachweis der Mauerwespe Sceliphron destillatorium Illiger, 1807 (Hymenoptera: Sphecidae) in Deutschland sowie ihr Auftreten nördlich der Alpen. Naturschutz südl. Oberrhein 3: $185-188$.

VAN DER VECHT J. \& VAN BREUGEL F. M. A. 1968. Revision of the nominate subgenus Sceliphron Latreille (Hymenoptera, Sphecidae) (Studies on the Sceliphronini, Part I). Tijdschrift voor Entomologie 111: 185-255.

WIŚNIOWSKI B. 2000. Blonkówki (Hymenopiera) polskich Bieszczadów ze szczególnym uwzględnieniem Bieszczadzkiego Parku Narodowego. Monografie Bieszczadzkie 8: 145-187.

WIŚNIOWSKI B. 2007. Dodatki do fauny błonkówek (Insecta, Hymenoptera) Ojcowskiego Parku Narodowego. Prądnik 17: $131-148$.

ZATOR A. 2004. Nalot ciepłolubnych. Dukielski Przegląd Samorządowy 3: 4-5.

\section{STRESZCZENIE}

[Występowanie Sceliphron destillatorium Illiger, 1807 (Hymenoptera, Sphecidae) w Polsce]

Na obszarze Polski stwierdzono lącznie 48 nowych stanowisk Sceliphron destillatorium Illiger, 1807, w tym 38 udokumentowanych oraz 10 nieudokumentowanych wymagajacych potwierdzenia. Na podstawie rozmieszczenia nowych stanowisk $S$. destillatorium oraz znanych z literatury wyznaczono obszar występowania tego gatunku na terenie Polski oraz północną granicę jego zasięgu. 